\title{
Errata
}

\section{Methods to Estimate Losses in Preemergence Herbicide Sprays}
A. G. F. Costa, C. G. Raetano, E. Negrisoli
E. D. Velini, G. R. Tofoli, A. L. Cavenaghi,

Department of Vegetable Production, College of Agronomy Sciences, São Paulo State University, Post Office Box 237, 18603-970, Botucatu-SP, Brazil

E. Negrisoli's name was inadvertently omitted from this article [Bull Environ.

Contam. Toxicol. (2005) 74:8-15, DOI: 10.1007/s00128-004-0541-7]. The corrected list of authors' names is printed here. 